\author{
Nitrifying membrane bioreactor에서의 \\ 막 오염 및 질산화 특성 \\ 임경조 · 홍순호 · 유익근 \\ 울산대학교 생명화학공학부 \\ (2011년 2월 10일 접수; 2011년 7월 29일 수정; 2011년 8월 11일 채택)
}

\title{
Characteristics of Membrane Fouling and Nitrification in Nitrifying Membrane Bioreactor
}

\author{
Kyoung Jo Lim, Soon Ho Hong, Ik-Keun Yoo* \\ School of Chemical Engineering and Bioengineering, University of Ulsan, Ulsan 680-749, Korea \\ (Manuscript received 10 February, 2011; revised 29 July, 2011; accepted 11 August, 2011)
}

\begin{abstract}
The purpose of this study is to find the operational characteristics of nitrifier-dominated membrane bioreactor (MBR), which has been extensively studied for organic removal, especially in terms of nitrite $\left(\mathrm{NO}_{2}-\mathrm{N}\right)$ build-up and membrane fouling. Membrane fouling is one of the important factor which determines the economics of MBR system. The characteristics of membrane fouling was monitored in terms of the fouling indices such as sludge volume index (SVI), the concentration of total organic carbon (TOC) and extracellular polymeric substances (EPS) in a membrane permeate or sludge extract, the absorbance of supernatant at $260 \mathrm{~nm}$. Most of index values except for protein concentration in EPS had a close relation with the increase of suction pressure and SVI value. Nitrifying MBR was superior to the conventional organic-oxidizing MBR in terms of membrane fouling since the fouling index value of nitrifying MBR was lower than that of BOD-oxidizing MBR.
\end{abstract}

Key Words : Membrane bioreactor, Fouling, Wastewater, Nitrification

\section{1. 서 론}

전통적인 활성슬러지 공정의 경우 오랜 기간의 경 험이 축적되어 왔음에도 불구하고 암모니아성 질소의 산화에 관련되는 질산화균의 낮은 성장속도 및 수율 로 인해서 다양한 상황의 질소폐수 처리에 있어서는 아직까지 약점을 보이고 있다(Wiesmann, 1994). 이를

\footnotetext{
${ }^{*}$ Corresponding author : Ik-Keun Yoo, School of Chemical Engineering and Bioengineering, University of Ulsan, Ulsan 680-749, Korea

Phone: +82-52-259-2251

E-mail: ikyoo@ulsan.ac.kr
}

해결하기 위해서 부분적인 개선책을 포함한 다양한 영양소 제거공정(BNR process)들이 제시되어 왔는데, $\operatorname{MBR}$ (membrane bioreactor) 역시 그 중의 하나이다 (Shim 등, 2002). 특히 MBR은 막에 의해 거의 $100 \%$ 의 미생물 체류가 가능하므로 질산화 균은 물론 그 외 의 성장속도 및 수율이 낮은 미생물 군집들을 시스템 내에 유지할 수 있는 장점이 있다.

MBR을 이용한 폐수처리 연구는 1980년대 말부터 특히 활발하게 이루어졌으며 현재는 기술적인 완성도 가 상당히 높아져 있는 상태이다. 그 동안 MBR을 이용 하여 유기물은 물론 유기물/질소 복합처리, 난분해성 물 질 처리 등 폭넓은 연구가 수행되어 왔다(Ghyoot 등, 
1999; Lim 등, 2004; Rosenberger 등, 2002). MBR은 크 게 외부순환형 막과 침지형 막의 두 가지 형태로 개발되 어 왔는데, 기존의 MBR 연구들은 유기물 산화가 주로 일어나는 환경 또는 유기물산화와 질산화가 동시에 일 어나는 환경에서의 운전결과가 대부분이다. MBR은 운 전시간이 증가할수록 막의 오염으로 인한 여과저항의 상승으로 막의 투과속도가 낮아지므로, 주기적인 세척 이 필요하거나 심한 경우 막 교체가 필요하게 되는 근본 적인 문제점이 있다. 이는 $\mathrm{MBR}$ 공정에서 가장 큰 문제 점으로서, $\mathrm{MBR}$ 운전과 관련된 많은 연구들은 막 오염 을 억제하거나막 오염 현상을 규명하는데 집중하고 있 다. 반면에 유기물 보다는 고농도 질소 처리 연구나, 아 예 유기물 산화 없이 질산화만이 반응기에서 유지되는 조건하에서의 $\mathrm{MBR}$ 연구는 드문 형편이다. 따라서 유기 물 산화가 일어나지 않는 순수 질산화MBR에서의 막 운 전 특성이나 막 오염 연구 역시 드물다.

이미 현장에서 널리 적용되고 있는 $\mathrm{MBR}$ 기술은 향 후에도 지속적으로 막 오염 현상을 이해하려는 노력 및 적절한 제어방법을 찾기 위한 연구가 활발할 것이 다. 본 연구에서는 앞에서 언급한 바와 같이 아직 연구 사례가 드문 순수 질산화 $\mathrm{MBR}$ 의 운전에 대해서 장기 간 모니터링한 결과를 제시하였다. 연구의 방법론은 장기간 유기물이 배제된 질소폐수의 공급에 따라 질 산화 슬러지가 MBR 내에서 우점되도록 하였으며, 이 를 통해 일반적인 질산화 특성을 살펴봄은 물론 순수 질산화 $\mathrm{MBR}$ 이 나타내는 운전특성, 막오염 현상을 검 토하였다. 운전 후반부에는 유기물산화를 동반한 기 존 연구사례와 비슷한 조건의 $\mathrm{MBR}$ 을 유지하였고, 전 단계의 순수 질산화 MBR과의 비교를 통해 이전의 $\mathrm{MBR}$ 연구에서는 제공되지 않았던 데이터를 제공하 고자 한다.

\section{2. 재료 및 방법}

\subsection{MBR 구성}

직사각형 형태의 아크릴로 제작된 유효 부피 $8 \mathrm{~L}$ 의 반응조에 중공사 침지형 막(Mitsubishi Rayon Co., 표 면적: $0.2 \mathrm{~m}^{2}$ )을 설치하였다. 반응기 하부에는 Fig. 1 에서와 같이 직경 $1 \mathrm{~mm}$ 의 구멍이 있는 산기관을 설치하 여 공기를 하부로부터 공급하였다. 유입 원수는 peristaltic pump를 이용하여 일정하게 공급하고, 흡입펌프는 diaphram type의 펌프를 이용하였으며 흡입펌프 사이에 압력계 를 설치하여 흡입압력을 측정하였다. 흡입펌프는 on-off timer에 의해 흡입 8 분, 정지 2 분으로 평균적으로 유 지하였다.

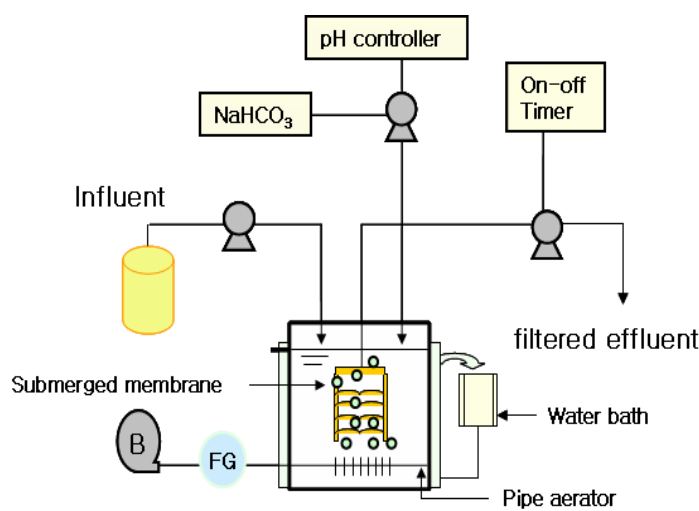

Fig. 1. Submerged hollow fiber membrane bioreactor system.

\subsection{MBR 운전조건}

이미 배양되고 있던 질산화 박테리아를 반응기에 접 종한 후 운전을 시작하였다. 공기유량은 $5-10 \mathrm{~L} / \mathrm{min}$ 의 범위에서 운전조건에 따라 변경하였다. $\mathrm{pH}$ controller 에 의해 $1 \mathrm{M} \mathrm{NaHCO}$ 를 이용하여 $\mathrm{pH}$ 를 제어하였으 며, water jacket에 의해 온도를 일정하게 유지하였다. 흡입펌프의 작동-정지 시간을 조절하여 유입수의 반 응기 체류시간이 12 시간으로 유지되도록 하였으며, 유입수의 질소 농도를 $1000 \mathrm{mg} / \mathrm{L}$ 로 유지한 18 일 이 후에는 $2 \mathrm{~kg} / \mathrm{m}^{3} \cdot \mathrm{d}$, 질소 농도를 $500 \mathrm{mg} / \mathrm{L}$ 로 변화시 킨 250 일 이후에는 $1 \mathrm{~kg} / \mathrm{m}^{3} \cdot \mathrm{d}$ 의 질소 부하가 $\mathrm{MBR}$ 에서 유지되었다. SRT를 구간에 따라 60,20 일로 각 각 조절하였다. 306 일 이후에는 다른 조건은 동일하 게 유지하면서 질소 합성폐수에 유기물을 $\mathrm{BOD}$ 기준 으로 $50 \mathrm{mg} / \mathrm{L}$ 추가로 공급하여 질산화균 이외에 유기 물 산화균의 성장을 촉진하였다.

\section{3. 폐수의 조성}

Table 1과 같이 암모늄염을 포함한 합성폐수를 유 입수로 사용하였으며 yeast extract에 포함된 일부를 제외하고는 유기 탄소원을 배제한 조성을 이용하였 다. 단, 운전 후반부에는 유기물을 추가로 공급하여 유 
기물/질소 산화 조건을 MBR에서 유도하였는데 Table 1 의 조성에 $\mathrm{CH}_{3} \mathrm{COOH}$ 를 $\mathrm{ThOD}$ (theoretical oxygen demand) 기준으로 $50 \mathrm{mg} / \mathrm{L}$ 첨가하였다.

Table 1. Composition of synthetic nitrogen wastewater

\begin{tabular}{cc}
\hline Component & Concentration \\
\hline \hline$\left(\mathrm{NH}_{4}\right)_{2} \mathrm{SO}_{4}$ & $100-1000 \mathrm{mgN} / \mathrm{L}$ \\
$\mathrm{NaHCO}_{3}$ (as $\left.\mathrm{CaCO}\right)$ & $3-7.1 \mathrm{mg} / \mathrm{mgN}$ \\
$\mathrm{MgSO}_{4} \cdot 7 \mathrm{H}_{2} \mathrm{O}$ & $50 \mathrm{mg} / \mathrm{L}$ \\
$\mathrm{CaCl}_{2} \cdot 2 \mathrm{H}_{2} \mathrm{O}$ & $50 \mathrm{mg} / \mathrm{L}$ \\
$\mathrm{KH}_{2} \mathrm{PO}_{4} \cdot \mathrm{H}_{2} \mathrm{O}$ & $50 \mathrm{mg} / \mathrm{L}$ \\
$\mathrm{FeSO}_{4} \cdot 7 \mathrm{H}_{2} \mathrm{O}$ & $2 \mathrm{mg} / \mathrm{L}$ \\
$\mathrm{MnSO}_{4} \cdot \mathrm{H}_{2} \mathrm{O}$ & $1 \mathrm{mg} / \mathrm{L}$ \\
yeast extract & $50 \mathrm{mg} / \mathrm{L}$ \\
\hline
\end{tabular}

\section{4. 분석방법}

폐수의 분석은 Standard Method(APHA, 1992)에 따라 실시하였다. 암모니아성 질소 $\left(\mathrm{NH}_{4}{ }^{+}-\mathrm{N}\right)$ 의 농도 는 네슬러(Nesslerization)법에 의해 $425 \mathrm{~nm}$ 에서 측정 하였으며, $\mathrm{NO}_{2}^{-}-\mathrm{N}, \mathrm{NO}_{3}^{-}-\mathrm{N}$ 의 농도는 이온 크로마토 그래프(Basic IC, Metrohm)로 분석하였다. $\mathrm{NO}_{2}^{-}-\mathrm{N}$ 은 디아조반응(Diazotization)에 근거한 Hach 분석키트 (Hach 8507)로도 병행하여 분석하였다. 용존산소는 DO meter(YSI 55)를 이용하여 측정하였다. 활성슬러 지 플록에서 $\mathrm{EPS}$ 를 추출하는 방법은 열처리법을 적 용하였다(Brown과 Lester, 1980). 추출된 상등액에서 단백질 분석은 단백질 분석키트(P 5656, Sigma)에 의해 $750 \mathrm{~nm}$ 에서 수행하였고 다당류 성분은 페놀-황산법 ((Dubois 등, 1956)으로 분석하였다. TOC(TOC-5000A, Shimadzu)및 $260 \mathrm{~nm}$ 에서의 흡광도인 E260은 MBR 슬러지액을 원심분리하거나 또는 막 여과액을 이용하 여 측정하였다. 폐수처리장에서의 유기탄소량을 측정 하기 위한 간접지표로서 E260 값과 같은 UV 흡광도 가 이용되고 있으며, 특히 부식질(humic substance)과 같이 복합 이중결합을 포함한 성분의 측정에 효과적 이다(Chevakidagarn, 2007). 막 오염 연구에서도 이러 한 성분이 막 오염과 연관이 있다는 것이 알려지면서 자주 언급되고 있으므로, 본 연구에서도 E260 값을 막 오염 지표의 하나로서 측정하였다.

\section{3. 결과 및 고찰}

\section{1. 질산화 $\mathrm{MBR}$ 의 슬러지 침전성과 질산화 효율}

Fig. 2는 유기물이 배제된 질소폐수를 이용하여 1 년 이상 장기간 운전한 $\mathrm{MBR}$ 에서의 슬러지 농도 (MLSS)와 sludge volume index(SVI)의 변화를 나타 낸 것이다. 전통적으로 슬러지의 침전성을 나타내는 지표인 SVI 변화는 기존의 MBR 연구에서는 소홀히 여겨져 왔던 부분인데, 본 연구팀이 MBR을 장기간 운영한 경험으로는 슬러지의 침전특성 변화가 장기 운전 과정에서의 막 오염과 관련이 있었다(Shim 등, 2002). 사실 MBR은 기존의 중력식 침전 활성슬러지 공정에서 중요한 운전요소인 SVI 문제로부터 자유로 운 장점이 있다고 알려졌으나, 본 연구진의 경험으로 는 $\mathrm{MBR}$ 기술에서도 역시 슬러지의 침전성을 전혀 무 시할 수는 없었다. 따라서 분리막의 세척 주기를 최대 한 길게 유지하거나 $\mathrm{MBR}$ 의 안정성을 최대한 확보하 기 위해서는 슬러지가 정상적인 플록을 형성하는 것 이 중요하다고 판단된다.

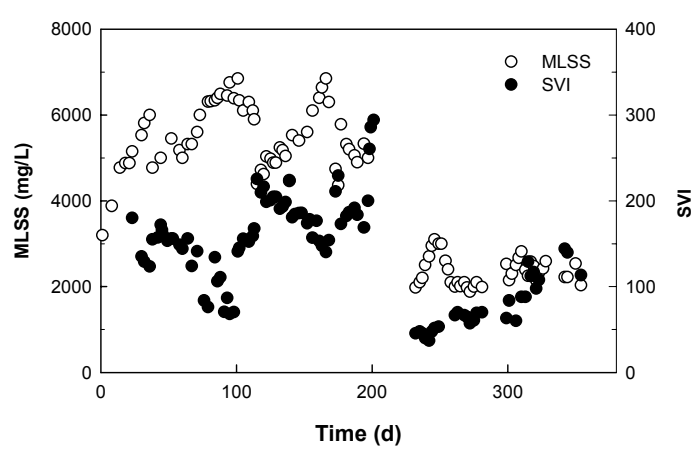

Fig. 2. Variation of sludge concentration (MLSS) and sludge volume index (SVI) in a nitrifying MBR.

Fig. 3 에는 질산화 지표인 암모니아성 질소 $\left(\mathrm{NH}_{4}{ }^{+}-\mathrm{N}\right)$, 아질산성 질소 $\left(\mathrm{NO}_{2}^{-}-\mathrm{N}\right)$, 질산성 질소 $\left(\mathrm{NO}_{3}^{-}-\mathrm{N}\right)$ 의 농도 변화를 나타냈다. Fig. 2 와 Fig. 3 을 비교해보면 SVI 값이 상승한 $100-200$ 일 구간 사이에서는 처리수의 암 모니아성 질소 농도 (eff. $\left.\mathrm{NH}_{4}{ }^{+}-\mathrm{N}\right)$ 가 상승하고 있는데, 즉 질산화 슬러지의 침전효율 저하와 암모니아성 질 소의 산화율이 비슷하게 일어나는 것을 알 수 있다. 반 면에 초기 100 일 동안에는 SVI 값이 50 근처까지 떨 


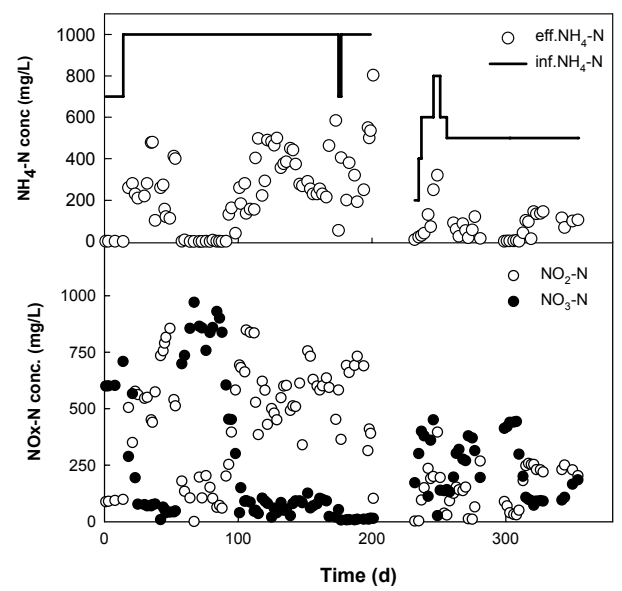

Fig. 3. Nitrification characteristics in a nitrifying MBR.

어지는 등 질산화 슬러지의 우수한 침전특성이 잘 나 타나고 있다. 운전 초기와 100 일 이후의 MBR 운전조 건이 거의 동일함에도 불구하고 100 일 이후에 질산화 슬러지의 침전성이 변화하는 구체적 원인에 대해서는 본 연구에서 더 이상 검토해보지는 못했으며 향후 이 에 대한 별도의 연구가 필요해 보인다. 사실 질산화 우 점 슬러지에 대한 연구는 기존 문헌에서도 찾아볼 수 가 없는데, 이는 통상적인 폐수처리장의 운전 조건이 유기물 및 질산화를 동시에 유도하기 때문일 것이다. FISH(Fluorescence In Situ Hybridization)과 같은 미 생물 군집 분석 방법을 활용한 별도의 연구가 필요하 다. 일반적으로 슬러지 체류시간(SRT)과 폭기조 내의 슬러지 농도는 어느 정도 비례하지만, 침전성은 과도 한 체류시간에서는 핀 플록이 형성되는 등 악화되는 것으로 알려져 있다. 본 연구진의 유기물 산화 MBR 연구에서도 SRT가 길 경우 장기간 운전 과정에서 슬 러지의 침전성이 극히 악화되었고 막 오염의 심화와 밀접한 관련이 있었다(Shim 등, 2002). 따라서 SVI의 변화 역시 $\mathrm{MBR}$ 의 정상적인 운전 과정에서 모니터링 해야 되는 주요 변수라고 판단된다.

슬러지 농도 변화를 살펴보면 초기 200 일의 운전기 간은 SRT를 60 일로 유지하였으며 그 이후는 20 일로 감소시켜 운전하여, 60 일에서는 MLSS가 5,500-7,000 $\mathrm{mg} / \mathrm{L}$ 사이에서 유지되었으나 20일에서는 2,000-2,500 $\mathrm{mg} / \mathrm{L}$ 내외로 유지되었다. 110 일 근처에서는 운전 사
고로 슬러지가 외부로 유출되어 MLSS가 급격히 감소 하였으나 점차 회복되었다. 160-200일 구간에서 SVI 는 150 에서 300 정도까지 급격히 증가하였는데, Fig. 3 에서 볼 수 있듯이 회복되던 암모니아성 질소의 산화 율이 다시 악화되어 처리수의 암모니아성 질소 농도 가 급격히 증가하는 것을 볼 수 있다. 특히 슬러지의 색깔 변화, 거품 발생 등 비정상적인 상태가 관찰되었 고, SRT를 60 일로 길게 유지한 것이 원인이 아닐까 추측하여 이후부터는 SRT를 20 일로 줄여서 $\mathrm{MBR}$ 이 안정화되는지 모니터링 하였다. 사실 100-200일 구간 사이에서 변화된 MLSS 농도를 고려해볼 때, 전체적 인 질산화 효율의 감소는 결국 단위 미생물당 비산화 효율(specific ammonium oxidation rate, g/gMLSS · d)이 감소하였기 때문이다. 순환형 막을 이용한 기존 의 MBR 연구에서도 비슷하게 원인을 알 수 없는 질 산화 효율의 감소 및 거품발생 현상이 관찰되었다 (Ghyoot 등, 1999). 해당 연구자들의 추측으로는 슬러 지 혼합액을 외부의 막 여과를 위해 고속으로 재순환 시킬때 슬러지에 부과되는 shear stress가 원인으로 제 시되었다. 그러나 본 연구에서는 침지형 막을 사용했 으므로 동일한 원인으로 설명되지 않고, 따라서 shear stress와 같은 물리적 원인 이외에 다른 생물학적 이유 가 있는 것으로 보인다. 마찬가지로 장기간 질산화 슬 러지를 유지하면서 미생물의 특성 변화와 같은 별도 의 연구가 요구된다.

\section{2. 질산화 $\mathrm{MBR}$ 의 아질산성 질소 축적}

Fig. 3 에서 초기 약 3 달간은 $\mathrm{DO}$ 를 $0.5 \mathrm{mg} / \mathrm{L}$ 미만에 서 유지하였다. 이때 암모니아성 질소 농도는 100 $\mathrm{mg} / \mathrm{L}$ 미만으로 유지되었고 아질산성 질소의 비율은 높게 측정되었다. 아질산성 질소의 비율이 높게 유지 된 원인은 크게 두 가지로 추측되는데, 용존산소에 대 한 친화력 및 free ammonia(FA, $\left.\mathrm{NH}_{3}-\mathrm{N}\right)$ 저해의 영향 이 암모니아 산화균과 아질산 산화균에게 각각 다르 게 나타났기 때문이다(Garrido 등, 1997; Kim 등, 2003; Yoon 등 2003). 우선 FA 저해의 경우 기존의 질산화 연구에서 이미 질산화균이 $\mathrm{FA}$ 농도에 따라 다 르게 저해받는다는 사실이 보고되었다. 암모니아 산 화균은 $\mathrm{FA}$ 기준으로 8-124 mgNH 3 - $\mathrm{N} / \mathrm{L}$ 범위에서 아 질산 산화균은 0.1-0.8 mgNH $3-\mathrm{N} / \mathrm{L}$ 에서 활성 저해가 
일어났는데 즉, 아질산 산화균에 미치는 저해 효과가 훨씬 더 큼을 알 수 있다(Anthonisen 등, 1976; Kim 등, 2003). FA 농도는 $\mathrm{pH}$ 및 암모니아성 질소 농도에 따라 다르게 나타나지만 $\mathrm{pH}$ 변화가 심하지 않게 되면 결국 암모니아성 질소 농도가 높을수록 FA 농도가 높 아지게 된다. 본 연구에서도 암모니아성 질소의 농도 가 비교적 높게 유지되면서, 비례적으로 반응기 내에 서의 FA 농도가 증가하였고 이로 인해 아질산 산화균 에 대한 저해 효과가 커졌다고 볼 수 있다.

또한 암모니아 산화균은 아질산 산화균에 비해 산 소에 대한 친화력이 높아서 산소 농도를 낮게 조절하 면 아질산 산화균의 활성을 억제할 수 있다(Kim 등, 2003). FA에 비해서 낮은 산소 농도에 대해 아질산 산 화균이 적응하는 현상은 아직 보고된 바 없다. 따라서 산소 농도를 적절히 조절하거나 혹은 FA 농도 저해와 병행하여 시스템을 유지하면 아질산 산화균을 효과적 으로 저해할 수 있을 것이다. 본 연구에서도 이와 같은 두 가지 인자에 의해 아질산성 질소가 축적되는 것으 로 보인다. 55 일 이후에는 일시적으로 $\mathrm{DO}$ 농도를 1 $\mathrm{mg} / \mathrm{L}$ 내외로 증가시켰는데 대부분의 암모니아성 질 소가 산화되면서 아질산성 질소의 비율이 감소하였다. 92 일 이후에 다시 DO 농도를 $0.3 \mathrm{mg} / \mathrm{L}$ 정도로 유지하 였더니 암모니아성 질소 농도가 $100-300 \mathrm{mg} / \mathrm{L}$ 범위로 증가하면서 아질산성 질소의 비율이 증가하였다.

$\mathrm{SRT}$ 가 20일로 유지된 후반부에는 암모니아성 질 소 농도가 $10 \mathrm{mg} / \mathrm{L}$ 이하로 낮게 유지되면서 거의 질 산성 질소로의 완전 질산화가 이루어졌다. 즉 $\mathrm{DO}$ 농 도가 낮더라도 반응기 내의 암모니아성 질소 농도가 낮아서 FA 농도가 낮게 유지될 경우에는 아질산 산화 균에 대한 저해 효과가 약한 것으로 보인다. 306일 이 후에는 기존 합성 질소폐수에 초산을 섞어 공급하였 는데, 처리수의 암모니아성 질소 및 FA 농도가 점차 증가하였고 이로 인해 아질산성 질소의 비율이 다시 증가하였다. MLSS는 2100에서 $2350 \mathrm{mg} / \mathrm{L}$ 내외로 $10 \%$ 정도 증가하였고 특히 SVI 값이 67에서 117로 증가하였다. 직전 단계의 순수 질산화 $\mathrm{MBR}$ 에 비해 $\mathrm{MBR}$ 내에서 유기물 산화균의 비율이 점차 증가하였 고 이로 인해 질산화 슬러지에 비해 침전성이 저하되 는 현상으로 보인다. 그러나 이 정도의 SVI 값은 통상 적인 유기물/질소 산화 폐수 처리장의 SVI 값과 비슷
하다고 볼 수 있다.

\section{3. 질산화 $\mathrm{MBR}$ 의 막오염 특성}

질산화 $\mathrm{MBR}$ 의 운전 과정에서 나타난 막 오염 특성 을 여러 가지 지표를 이용하여 살펴보았다. 우선 labscale로 MBR을 만들었기 때문에 효율적인 막 오염 억제를 위한 설계가 반영되지 않았음에도, 1 년이 넘는 운전 기간 동안 막 모듈의 교체가 없었고 질산화 $\mathrm{MBR}$ 의 운전 안정성이 높음을 알 수 있다. 기존 연구에서는 막 오염과 관련된 인자로서 분리막 자체의 특성, 분리 막 모듈의 운전 조건 외에 여과 대상물질인 슬러지액 의 특성이 중요하게 거론되어 왔다. 본 연구에서는 상 업적으로 판매되는 중공사막 모듈 및 표준화된 운전 방법을 적용했고, 막 오염과 관련된 생물학적 지표로 기존의 유기물 산화 MBR 연구에서 흔히 제시된 EPS(Extracellular Polymeric Substance), TOC(Total Organic carbon), $260 \mathrm{~nm}$ 에서의 흡광도인 E260을 측 정하였다. 이와 같은 막 오염 지표가 질산화 $\mathrm{MBR}$ 의 막 오염을 나타내는 흡입압력 상승과 어느 정도 관련 이 있는지 측정하였으며, 운전기간 60-120일 사이에 측정된 결과를 Fig. 4에 나타내었다. EPS, TOC, E260 모두 증가 할수록 막의 흡입압력도 비례적으로 증가

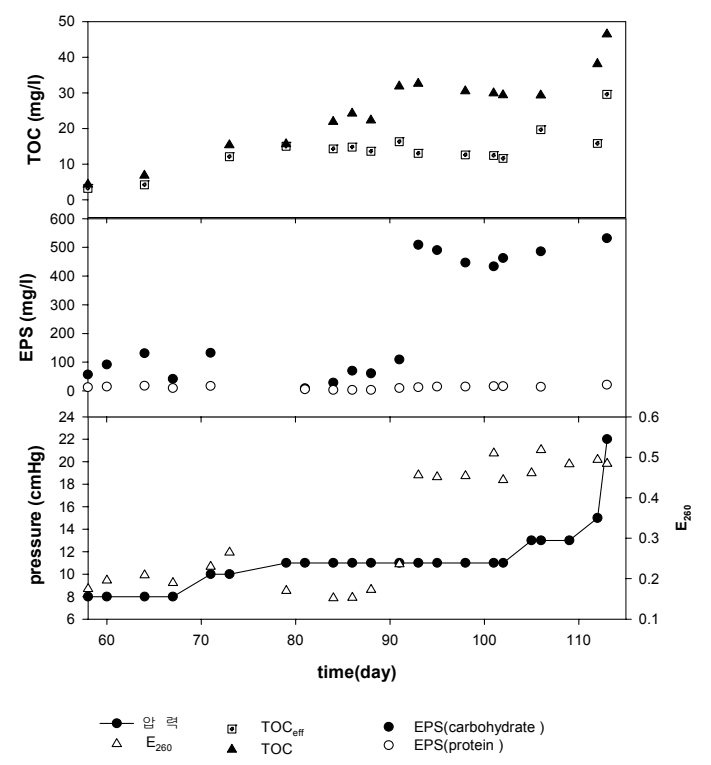

Fig. 4. Variation of membrane fouling factor and suction pressure in MBR. 
하여 서로 상관 관계가 있음을 알 수 있다. EPS의 구 성성분 중에서 단백질의 경우는 막 오염과 큰 상관관 계가 없었고, 반면에 다당류 EPS 및 E260 값의 상승 이 막 오염을 보다 직접적으로 표현하여 막의 흡입압 력 상승과 같이 일어났다. TOC의 경우는 막 투과수의 $\mathrm{TOC}$ 에 비해서는 슬러지 상등액의 TOC가 보다 막의 흡입압력 상승을 잘 나타내는 것으로 보인다.

SRT 20일로 유지된 운전 후반부에 유기물을 유입 폐수에 첨가하여 $\mathrm{BOD} / \mathrm{N}$ 동시산화 $\mathrm{MBR}$ 로서 운전된 결과와 200 일까지 운전된 순수 질산화 MBR과의 막 오염 지표를 비교하여 보았다. 220 일에서 305 일까지 앞과 같이 질소폐수가 공급된 MBR은 N MBR, 306일 이후 유기물이 투입된 이후에 운전된 $\mathrm{MBR}$ 은 $\mathrm{BOD} / \mathrm{N}$ $\mathrm{MBR}$ 로 명칭하여 얻어진 3 개의 시료에 대한 평균값 을 Fig. 5에 나타내었다. 306일 이후에는 추가 유기물 공급에 의해 MLSS가 증가하였으므로, 동일한 MLSS 농도 기준에서 계산된 값을 비교하기 위해 Fig. 5 의 값 은 MLSS $1000 \mathrm{mg} / \mathrm{L}$ 기준으로 보정된 값이다. 안정 적으로 운전되는 질산화 $\mathrm{MBR}$ 은 유기물 공급이 없었 기 때문에 상대적으로 막 오염에 영향을 크게 미치는 $\mathrm{E} 260$ 값과 다당류 EPS 값이 모두 낮게 나타나는 것을 알 수 있다. 따라서 유기물이 공급되는 유기물 산화 $\mathrm{MBR}$ 에 비해서 순수 질산화 $\mathrm{MBR}$ 의 막 오염이 상대 적으로 완화될 수 있었던 원인으로 보인다.

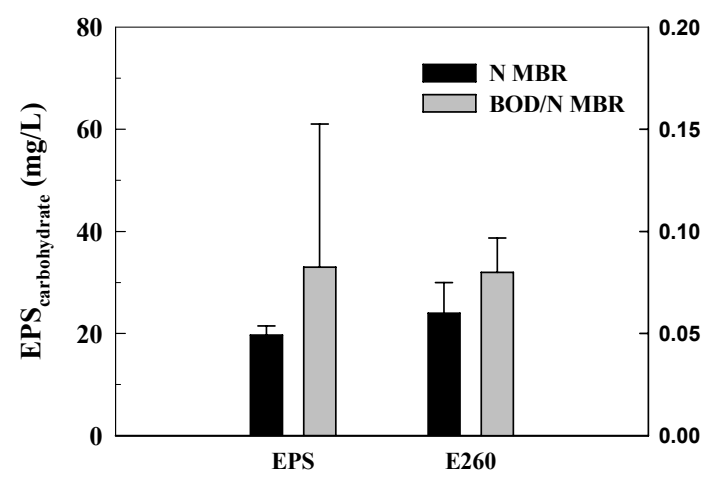

Fig. 5. Comparison of EPS and E260 between a nitrifying MBR and a BOD/N oxidizing MBR.

\section{4. 결 론}

기존의 유기물 산화 $\mathrm{MBR}$ 에 비해 아직까지 보고된
사례가 드문 순수 질산화 $\mathrm{MBR}$ 을 장기간 운전한 결과 다음과 같은 결론을 얻었다.

1. 유기물이 배제된 $1000 \mathrm{mgN} / \mathrm{L}$ 농도의 질소 폐수 를 공급하면서 MBR 내의 DO를 0.3-1 mg/L 내 외로 유지했을 때 DO 농도가 상대적으로 낮은 환경에서 아질산성 질소가 $\mathrm{MBR}$ 에 축적되었다. 원인으로는 암모니아 산화균에 비해 아질산 산화 균의 산소 친화력이 낮고, free ammonia( $\left.\mathrm{NH}_{3}-\mathrm{N}\right)$ 에 의한 저해 효과가 더 크게 작용하기 때문으로 보인다.

2. 질산화 슬러지로 우점되어 안정적으로 운전되는 질산화 $\mathrm{MBR}$ 에서는 SVI 값이 100 이하의 침전 성이 우수한 슬러지가 유도되었으나, 연속 운전 후 약 3-6개월 사이 기간에 SVI 값이 점차 상승 하여 300 까지 이르렀다. SVI 값이 300 까지 증가 했을때는 질산화 슬러지의 색깔 변화, 거품 발생 현상도 동반되면서 암모니아성 질소의 산화 효 율도 악화되었다. 정확한 원인은 본 연구에서 밝 히지 못했으며, 이와 같이 운전 과정에서 질산화 슬러지의 침전성이 변화하는 이유에 대해서는 후속 연구가 필요하다.

3. SRT 60 일 조건에서 $1000 \mathrm{mgN} / \mathrm{L}$ 유입 질소가 평균 $80 \%$ 정도 산화될 때 $\mathrm{MBR}$ 의 질산화슬러지 농도는 5000-7000 mg/L로 유지되었으며, SRT 20 일에서 $500 \mathrm{mgN} / \mathrm{L}$ 유입 질소가 평균 $90 \%$ 산 화하는 조건에서는 $2000-2500 \mathrm{mg} / \mathrm{L}$ 내외로 유 지되었다.

4. 질산화 $\mathrm{MBR}$ 의 막 오염 특성을 알아보기 위해 EPS, TOC, E260의 세가지 지표를 측정하여, 막 운전시 흡입압력 상승과의 관련도를 살펴보았 다. 세 가지 지표 모두 막의 흡입압력 상승에 따 라 증가하는 모습을 보였는데, 특히 다당류 EPS 및 E260 값이 증가하였을 때 막의 흡입압력도 증가하는 모습이 관찰되었다. 유기물 산화 MBR 과 순수 질산화 $\mathrm{MBR}$ 의 상대적 비교에서는 질산 화 MBR의 E260, 다당류 EPS 값이 낮았으며, 이 


\section{로부터 질산화 $\mathrm{MBR}$ 의 운전이 막 오염도 측면에 서 유기물 산화 MBR에 비해서 유리할 것으로 추측된다.}

\section{감사의 글}

본 연구는 2009년 울산대학교 교내연구비 지원으 로 수행되었습니다.

\section{참 고 문 헌}

APHA, 1992, Standard methods for the examination of water and wastewater, 18th ed., Washington DC.

Anthonisen, A. C., Loehr, R. C., Prakasam, T. B. S., Stinath, E. G., 1976, Inhibition of nitrification by ammonia and nitric Acid, J. Water Pollut. Con. F., 48, 835-852.

Brown, M. J., Lester, J. N., 1980, Comparison of bacterial extracellular polymer extraction methods, Appl. Environ. Microbiol., 40, 179-185.

Chevakidagarn, P., 2007, BOD5 estimation by using UV absorption and COD for rapid industrial effluent monitoring, Environ. Monit. Assess., 131, 445-450.

Dubois, M., Gilles, K. A., Hamilton, J. K., Rebers, P. A., Smith, F., 1956, Colorimetric method for determination of sugars and related substances, Anal. Chem., 28, 350-356.

Garrido, J. M., van Loosdrecht, M. C. M., Heijnen, J. J., 1997, Influence of dissolved oxygen concentration on nitrite accumulation in a biofilm airlift suspension reactor, Biotechnol. Bioeng., 53, 168-178.

Ghyoot, W., Vandaele, S., Verstraete, W., 1999, Nitrogen removal from sludge reject water with a membraneassisted bioreactor, Water Res., 33, 23-32.

Kim, D. J., Chang, J. S., Lee, D. I., Han, D. W., Yoo, I. K., Cha, G. C., 2003, Nitrification of high strength ammonia wastewater and nitrite accumulation characteristics, Water Sci. Technol., 47, 45-51.

Lim, B. R., Ahn, K. H., Songprasert, P., Lee, S. H., Kim, M. J., 2004, Microbial community structure in an intermittently aerated submerged membrane bioreactor treating domestic wastewater, Desalination, 161, 145-153.

Rosenberger, S., Kruger, U., Witzig, U., Manz, R., Szewzyk, U., Kraume, M., 2002, Performance of a bioreactor with submerged membranes for aerobic treatment of municipal wastewater, Water Res., 36, 413-420.

Shim, J. K., Yoo, I. K., Lee, Y. M., 2002, Design and operation considerations for wastewater treatment using a flat submerged membrane bioreactor, Process Biochem., 38, 279-285.

Wiesmann, U., 1994, Biological nitrogen removal from wastewater, Adv. Biochem. Eng. Biotech, 51, 692-699.

Yoon, H. J., Kim, D. J., 2003, Nitrification and nitrite accumulation characteristics of high strength ammonia wastewater in a biological aerated filter, J. Chem. Tech. Biotechnol., 78, 377-383. 